\title{
Monetary Policy and Inflation Targeting in Nigeria: The Need for Monetary-Fiscal Coordination
}

\author{
Christopher Nyong Ekong, Ubong Edem Effiong* \\ Department of Economics, Faculty of Social Sciences, University of Uyo, Uyo, Nigeria \\ Email address: \\ ubongeffiong3@gmail.com (U. E. Effiong) \\ ${ }^{*}$ Corresponding author \\ To cite this article: \\ Christopher Nyong Ekong, Ubong Edem Effiong. Monetary Policy and Inflation Targeting in Nigeria: The Need for Monetary-Fiscal \\ Coordination. American Journal of Theoretical and Applied Business. Vol. 6, No. 3, 2020, pp. 37-46. doi: 10.11648/j.ajtab.20200603.14
}

Received: September 27, 2020; Accepted: October 12, 2020; Published: October 21, 2020

\begin{abstract}
This paper examined the effectiveness of a monetary-fiscal coordination in inflation targeting in Nigeria for the period 1985 to 2019. The study got its inspiration from the monetarist assertion that inflation is strictly a monetary phenomenon. Data were obtained from the Central Bank of Nigeria statistical bulletin and the World Bank database on World Development Indicators. The study employed the Augmented Dickey-Fuller unit root test, ARDL bounds test for cointegration, and the Error Correction Mechanism (ECM). The unit root test revealed that the variables were stationary at mixed order of level I(0) and first difference I(1). This mixed order made us to employ the ARDL Bounds test for cointegration and the result indicated that there is a long run relationship. The Error Correction Mechanism revealed that 55.4\% of the short run disequilibrium is corrected annually. Meanwhile, the study revealed that both monetary policy channels and fiscal policy significantly influence inflation both in the long run and in the short run. The paper concludes by stating that there is a need for a sound monetary-fiscal coordination in the Nigerian economy if the fight against inflation is to be won hence, inflation should not only be viewed as a monetary phenomenon.
\end{abstract}

Keywords: Monetary-Fiscal Coordination, Inflation Targeting, Monetary Policy Rate, Liquidity Ratio, ECM

\section{Introduction}

Inflation targeting is a monetary policy strategy in which central bank estimates and makes public a target inflation rate and then, attempts to steer actual inflation towards the target through the use of other key macroeconomic variables such as interest rate changes and other monetary tools [1]. It is a framework in which the primary goal of monetary policy is to achieve price stability in form of an inflation target. Such targeting is done using various monetary policy tools such as cash reserve ratio, liquidity ratio, open market operations, discount window operations, monetary policy rate, and exchange rate [1]. Inflation targeting has been reported to be conducted in three different forms viz: (i) Full-Fledged Inflation Targeting (FFIT)-where countries set a medium to high level of credibility, clearly committed to their inflation target, and institutionalize this commitment in the form of transparent monetary framework that fosters accountability of the central bank to the target; (ii) Eclectic Inflation Targeting (EIT) - where countries command sufficient credibility that can afford them to maintain low and stable inflation without full transparency and accountability; and (iii) Inflation Targeting Lite (ITL) - where countries announce a broad inflation objective, but owing to relatively low credibility (an indication of vulnerability to large economic shocks, financial instability and a weak institutional framework), are not able to maintain inflation as the foremost policy objective [1]. This spectacular monetary policy framework was earlier adopted by countries such as United Kingdom in 1992 New Zealand in 1990, Canada in 1991, Sweden in 1993, Norway in 2001, Finland in 1993, Iceland in 2001, and Australia in 1993; while early adopters of IT in emerging market economies include South Korea in 2001, Brazil in 1999, Mexico in 2001, Poland in 1998, Czech Republic in 1997, Thailand in 2000, South Africa in 2000, Colombia in 1999, Hungary in 2001, Chile in 1999, Israel in 1997, and Peru in 2002. Other countries that later joined include Slovakia in 2005, Romania in 2005, Turkey in 2006, and Ghana in 2007 [1, 2].

There have been records of the benefits derived from 
inflation targeting in countries that adopted them. This include low inflation rate, reduction in output loss, reduction in target misses, and improved financial system stability [1]. Meanwhile, for such benefits to be derived, inflation targeting needs to be carried out under a solid foundation. Such preconditions include a good model for forecasting inflation over the medium term horizon of at least two to three years; the model should be operationalized and used to track the deviation of actual inflation from forecast for at least two years, and adjudged to be efficient before the bank adopts the inflation target; the Central Bank would have to determine which inflation to adopt: CPI or Retail Price Index (RPI); ascertain the level of inflation expectation by the economic agents and the central bank legislation on adoption of the monetary policy framework; communication needs must be adequately identified and channels appropriately defined; and the level of inflation that is consistent with the desired level of economic activities in the economy should be ascertained [1]. These preconditions were summed into two key perspectives by Masson, Savastano, and Sharma to include that the central bank of the country must be in a position to conduct its monetary policy with a strong degree of instrument independence; and that the country must not be committed to targeting the level or path of any other nominal variable [3, 4].

The rising rate of inflation in Nigeria and its pervasive effects on the economy is a crucial issue for national concern.
This has made inflation targeting a dominant monetary policy focus of the Central Bank of Nigeria on the assumption that it is an essential tool of achieving macroeconomic stability [5]. Inflation in the 1985 and 1986 maintained a single digit but hovered between $50 \%$ and 54\% between 1988 and 1999 . The period 1991 to 1996 was characterised by a double digit inflation averaging $45.65 \%$ within the period. Meanwhile, monetary policy was geared towards enhancing price stability which brought back the inflation rate to a single digit between 1997 to 2000 averaging 8.02\%. Also, the drastic growth in money supply to $48.07 \%$ moved the economy back to a double digit inflation between 2001 to 2005 averaging $15.73 \%$. This was reversed in 2006 and 2007 but the economy reverts back to her double digit inflation between 2008 and 2012 averaging 11.98\%. Between 2013 and 2015, inflation averaged $8.52 \%$, maintaining a single digit but returned to a double digit between 2016 and 2019 averaging $13.92 \%$. Within the review period, the highest inflation rate of $72.84 \%$ was witnessed in 1995 with a least of $5.38 \%$ experienced in 2007.

However, inflation targeting should not only be done under a framework of a strict monetary phenomenon. This is because lack of coordination in both monetary and fiscal spheres will ultimately leads to policy misses. Evidence of this is presented in Figure 1 where we observed a direct relationship between inflation and growth rate of government expenditure.

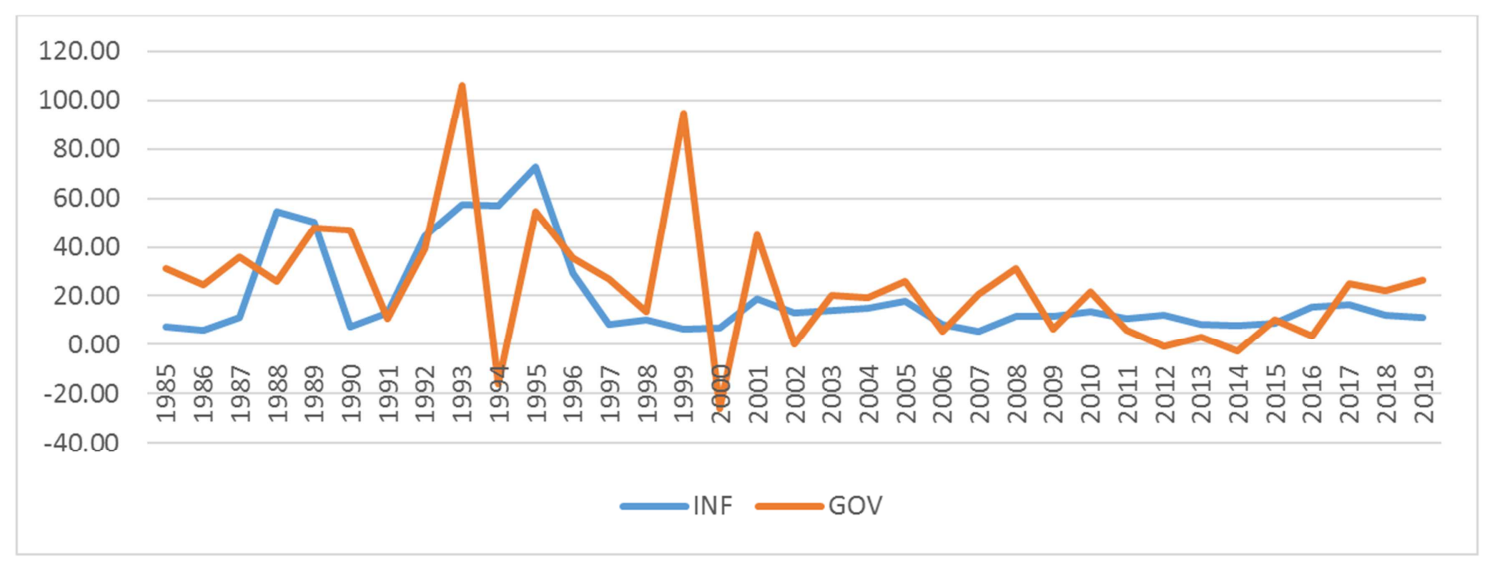

Figure 1. The reaction of Inflation to growth rate of government expenditure.

As evidenced in figure 1, we observe the oscillating nature of inflation in response to the oscillating nature of the growth rate of government expenditure. Periods of great oscillations in the growth rate of government expenditure (like in 1985 to 2001) were followed by oscillations in inflation. However, a stable growth rate in government expenditure is also occasioned with a steady inflation, such as the period 2003 to 2019. This calls for concern that inflation targeting should take full considerations of fiscal actions if the target is to be achieved. No wonder it is opined that monetary policy in Nigeria needed to be supported by contractionary fiscal policy if the desired objectives are to be achieved [6].

An overview of the inflation targets and outcomes will reveal that the need for monetary-fiscal coordination is of great importance. This is presented in Table 1.

Table 1 Inflation Rates targets and outcomes (Growth Rates).

\begin{tabular}{llllllll}
\hline Year & Target & Outcome & Growth rate of Government Expenditure & Year & Target & Outcome & Growth rate of Government Expenditure \\
\hline 1985 & 1.0 & 30.00 & 31.36 & 2003 & 23.80 & 9.00 & 20.41 \\
1986 & 13.70 & $* * *$ & 24.40 & 2004 & 10.00 & 10.00 & 19.24 \\
1987 & 9.70 & $* * *$ & 35.72 & 2005 & 11.60 & 10.00 & 25.91 \\
1988 & 61.20 & $* * *$ & 26.03 & 2006 & 8.50 & 9.00 & 5.53 \\
\hline
\end{tabular}




\begin{tabular}{llllllll}
\hline Year & Target & Outcome & Growth rate of Government Expenditure & Year & Target & Outcome & Growth rate of Government Expenditure \\
\hline 1989 & 44.70 & $* * *$ & 47.85 & 2007 & 6.60 & 9.00 & 20.90 \\
1990 & 3.60 & $* * *$ & 46.89 & 2008 & 15.10 & 9.00 & 31.07 \\
1991 & 23.00 & 13.00 & 10.48 & 2009 & 12.00 & 8.20 & 6.58 \\
1992 & 44.80 & 5.00 & 39.37 & 2010 & 11.80 & 11.20 & 21.72 \\
1993 & 61.30 & 25.00 & 106.07 & 2011 & 10.30 & 12.00 & 6.00 \\
1994 & 76.80 & $* * *$ & -15.86 & 2012 & 12.00 & 9.50 & -0.78 \\
1995 & 51.60 & 15.00 & 54.62 & 2013 & 8.00 & 9.90 & 2.94 \\
1996 & 14.30 & 30.00 & 35.64 & 2014 & 8.00 & 7.50 & -2.62 \\
1997 & 10.20 & 15.00 & 26.91 & 2015 & 9.60 & 8.00 & 10.46 \\
1998 & 11.90 & 9.00 & 13.75 & 2016 & 18.60 & 11.90 & 3.51 \\
1999 & 0.20 & 9.00 & 94.55 & 2017 & 15.40 & 10.71 & 25.11 \\
2000 & 14.50 & 9.00 & -26.03 & 2018 & 11.40 & 13.00 & 22.17 \\
2001 & 16.50 & 7.00 & 45.21 & 2019 & 11.98 & 11.74 & 26.22 \\
2002 & 12.20 & 9.30 & 0.02 & & & & \\
\hline
\end{tabular}

Note: $* * *$ denotes that policy statement is specified as significantly reduce/moderate the rate of inflation.

Source: [7].

From Table 1, we observe that a lot of targets have not been met and it was only as at 1986-19990 and 1994 that the monetary authority recorded a significant policy that reduce inflation in Nigeria. As stated earlier, the goal of price stability should be a balance of both monetary and fiscal actions. As such, a monetary policy target of reducing inflation in 1999 to $0.20 \%$ growth rate cannot be achieved when the growth rate of government expenditure rose from $13.75 \%$ in 1998 to $94.55 \%$ in 1999 .

This effect of fiscal actions on inflation targeting and the need for a monetary-fiscal coordination serves as the inspiration for this study. Therefore, this paper seeks to investigate the effectiveness of a monetary-fiscal coordination in inflation targeting in Nigeria. Specifically, the study seeks to investigate the effects of the various monetary policy transmission channels, such as growth rate of broad money supply, liquidity ratio, treasury bills rate, and interest rate, on inflation in Nigeria; as well as examining the effect of government expenditure on inflation in Nigeria.

The study is divided into five sections. Section I which is the introduction is followed by literature review in Section II. Section III captures the materials and methods utilized in the study while Section IV adumbrates the empirical findings. Finally, Section V presents the conclusion of the research.

\section{Literature Review}

Theories relating to inflation emanated right from the classical school of economic thought. To them, the rate of inflation in an economy is related to the quantity of money in circulation. Thus, the classicist utilized the quantity theory of money in explaining the root causes of inflation. Based on this, the general price level rises in proportion to the increase in money supply, with real output remaining constant. If the monetary authority increases money supply with velocity of circulation and output remaining constant, liquidity rises leading to greater demand for goods and services. This leads to an increase in the price level with a fall in real wage. This theory is criticized on the basis that it does not take into account, the non-monetary factors that can cause inflation [8].

In the Keynesian school, inflation arises when aggregate demand is greater than aggregate supply. That is, as aggregate demand rises above aggregate supply (excess aggregate demand) at full employment, prices tend to rise. Keynes regarded such excess of aggregate demand as 'inflationary gap'. To close this gap, Keynes stressed the need for a contractionary fiscal policy-reduction in government spending and/or increase in taxation - which will restore aggregate demand back to the full employment level of output.

The monetarist took their turn by strictly stating that 'inflation is a monetary phenomenon'. Hence, it should be handled using monetary measures. The monetarist utilized the equation of exchange ( $\mathrm{MV}=\mathrm{PY}$ ) in explaining the root cause of inflation. Thus an increase in money supply causes a proportionate increase in prices. Since velocity (V) and output (Y) are exogenously determined, inflation (P) is assumed to be determined by the rate of changes in money supply (M).

Empirical studies on the linkages between monetary policy and inflation targeting have been conducted over the years.

Mishkin and Savastano examined the changes in the monetary policy transmission mechanism in Colombia between 1989 and 2007 using a modified small open economy DSGE model to study the theoretical changes. The Markov switching VAR model was also utilized to compute and compare impulse responses. The results show that there is a clear difference between volatilities among the regimes and in particular the inflation targeting regime and is characterized by a low volatility of inflation and the interest rate. Also, it was observed that the transmission mechanism of monetary policy has become more effective in lowering inflation and interest rate volatility [9].

Naraidooa and Gupta investigated monetary policy modelling in South Africa using a nonlinear framework for the period 1983 to 2007 . The study revealed that modelling 'inflation learning rule' into its future policy plans gives better understanding of the actions of SARB. Findings further showed that implementation of inflation targeting monetary policy brought about dire changes in the country's policy conduct and that the farther away an inflation rate is from its target, the more it response became volatile [10]. 
Aliyu and Englama examined whether Nigeria is ready to adopt inflation targeting (IT). The study applied Vector Autoregressive (VAR) model to some selected monetary policy and other macroeconomic variables to study the various channels using the Granger causality tests, impulse responses, and variance decomposition. Findings of the study show that inflation in Nigeria is pokerfaced to monetary transmission variables in the model. A weak link between prices and credit and interest rate channels were established in the study; while evidence of strong inverse link between exchange rate and prices was found in the model [5].

Kadioglu, Ozdemir, and Yilmaz analysed the interface among interest rate, inflation and output under inflation targeting regime in Turkey for the period 2002-2006. The study utilized impulse response functions in Vector Autoregressive (VAR) analysis and Johansen co-integration approach to unravel the short and a long term relationship among inflation, interest rate and production. The impulse responses reveal that the increase in interest rates will lead to a decline in inflation rates by decreasing the aggregate demand in Turkish economy [11].

Gerlach and Tillmann investigated the effect of inflation targeting on inflation persistence in Asia Pacific (Indonesia, Korea, the Philippines and Thailand) using quarterly data from 1985Q1 to 2010Q1. Using a median unbiased estimator and bootstrapped confidence bands, the result showed that implementation of inflation targeting approach has reduced inflation significantly and that the rate of reduction is not the same among nations. Also, the study revealed that countries that do not embrace inflation targeting have no sign of fall in inflation dominance [12].

Poon and Kok analysed the applicability of inflation targeting in ASEAN countries. Their findings illustrate that both inflation targeting and non-inflation targeting ASEAN countries responds significantly to inflation gap; but neither of the groups responded significantly to the output gap in setting the interest rates. Their findings funder establishes that countries that adopt inflation targeting have lower exchange rate volatility compared to non-inflation targeting countries. The implication here is that inflation targeting does not seem to come as a "cost" to domestic economy with respect to higher exchange rate volatility [13].

Danjuma, Jibrin, and Blessing investigated the effectiveness of monetary policy in combating inflation pressure in Nigeria for the period 1980 to 2010. The study utilized classical least squares method which was augmented by the granger causality, stationarity test and correlogram test The results show that the liquidity ratio and interest rate are the effective monetary policy instruments that can be used to combat inflation in Nigeria. The paper recommended the need for proper management of liquidity ratio and interest rate variables so as to help in controlling inflation [14].

Chinaemerem and Akujuobi assessed whether the prerequisites for a successful inflation targeting framework is present in Nigeria and Ghana using the VAR model. The VAR model including variables like money supply and prices show that inflation is an inertial phenomenon in Nigeria and
Ghana. The result further shows that money innovations are not strong and statistically significant in determining prices when compared with price shocks. Also, innovations in prices are mostly explained by their own shocks, and the monetary policy instruments have little or no effect on prices in the short run. The study concludes that policy linkage between inflation and monetary policy instruments in Nigeria and Ghana is not strong in the short run and thus, these countries are not yet candidates for inflation targeting [15].

Odior examined inflation targeting in an emerging market using VAR and Impulse Response Function (IRF) Approach for the period 1970-2010. The model established the extent in which policy target of macroeconomics variables does lead to changes in inflation. The results show that, money supply and past level of inflation have the potentials of causing significant changes in inflation in Nigeria. It was recommended that more policy attention be given to these variables in order to have stable inflation rate in Nigeria [16].

Maku and Adelowokan investigated the dynamics of inflation in Nigeria using an Auto Regressive framework for the period 1970-2011. The study revealed that fiscal deficit and interest rate exerts slowing pressure on inflation dynamics in Nigeria. Also, macroeconomic indicators such as real output growth rate, broad money supply growth rate, and previous level of inflation rate exert accelerating pressure on inflation rate in Nigeria. The study recommends the need to ensure that monetary policy and fiscal policy are effectively harmonized and their objectives coordinated [17].

Tolulope and Ajilore examined inflation targeting monetary policy stance of Nigeria using Taylor Policy Rule. The study utilized quarterly data from 2000Q1 to 2010Q4 and was analysed using Engle- Granger approach to cointegration approaches. The result show that implementation of monetary policy function was effectively done in order to achieve price stability in the economy. The paper concludes by stating that that Nigeria's monetary policy needed to be followed by contractionary fiscal policy so as to be able to achieve the objective of price stability [6].

Aigbedion explored the applicability of inflation targeting in the Nigerian economy using quarterly data from 1990Q1 to 2014Q4. The study used unit root test, co-integration test, unrestricted VAR methodology, and impulse response analysis. The impulse response functions from the VAR model show that the response of CPI to its own shocks is contemporaneously very strong and remain so throughout the short and medium term horizons, but, less persistent afterwards. The response of CPI to innovations in money supply (liquidity channel) and interest rate (interest rate channel) were found to be less significant. The paper recommends that government should use exchange rate as inflation targeting instrument in Nigeria to reduce the level of imported inflation [18].

Finally, Okwori and Abu investigated the efficacy of monetary policy in curbing inflation in Nigeria using time series data for the period 1986-2015. The Vector Error Correction Model was used and the result revealed that monetary policy is significant in curbing inflation threshold 
in Nigeria, though such effects are weak in controlling inflation. The paper recommended that the Central Bank of Nigeria should narrow the asymmetric corridor around the MPR to check commercial banks excess reserves [4].

\section{Methodology}

\subsection{Model Specification}

In examining the effectiveness of monetary-fiscal coordination in tackling inflation in Nigeria, the model is specified as follows:

$$
\mathrm{INF}=f\left(M P R, \mathrm{TBR}, \mathrm{LRA}, \mathrm{M}_{2} \mathrm{G}, \mathrm{PLR}, \mathrm{UNM}, \mathrm{GOV}\right)
$$

Where: INF=Inflation Rate

$\mathrm{MPR}=$ Monetary Policy Rate

$\mathrm{TBR}=$ Treasury Bills Rate

LRA $=$ Liquidity Ratio

$\mathrm{M}_{2} \mathrm{G}=$ Growth Rate of Broad Money Supply

$\mathrm{PLR}=$ Prime Lending Rate (Interest Rate)

UNM=Unemployment Rate

GOV $=$ Growth Rate of Total Government Expenditure

Transforming Equation (1) from its functional form to an econometric model yields;

$$
\begin{gathered}
\mathrm{INF}=\xi+\vartheta_{1} \mathrm{MPR}+\vartheta_{2} T B R+\vartheta_{3} L R A+\vartheta_{4} \mathrm{M}_{2} \mathrm{G}+\vartheta_{5} P L R+ \\
\vartheta_{6} U N M+\vartheta_{7} G O V+\mu_{t}
\end{gathered}
$$

Where all the variables are as defined above; $\xi$ is the intercept (constant) of the regression line; $\vartheta_{1}$ to $\vartheta_{7}$ are the parameters to be estimated; and $\mu_{t}$ is the random error term assumed to be normally distributed.

\subsection{A priori Expectation}

The signs of the parameters estimates are expected to be as follows: $\vartheta_{2}, \vartheta_{3}, \vartheta_{4}$, and $\vartheta_{7}$ are expected to be positive. The implication is that a rise in any of the variables with these coefficients will result to a concomitant increase in inflation and vice versa. Similarly, $\vartheta_{1}, \vartheta_{5}$, and $\vartheta_{6}$ are all expected to be negative, implying that an increase in them will lead to a decrease in inflation and vice versa.

\subsection{Sources of Data}

This research utilizes secondary data from Central Bank of Nigeria and World Bank Database. Data on inflation rate (INF), monetary policy rate (MPR), Treasury bills rate (TBR), growth rate of broad money supply $\left(\mathrm{M}_{2} \mathrm{G}\right)$, prime lending rate (PLR), and growth rate of total government expenditure (GOV) were obtained from the Central Bank of Nigeria statistical bulletin of 2019; while data on unemployment (UNM) were obtained from World Bank database on World Development Indicators.

\subsection{Analytical Technique}

This study utilized the Augmented Dickey-Fuller (ADF) unit root test to test for the stationarity of the variables. The unit root test is performed under two assumptions: constant with no trend, and constant with a linear deterministic time trend. The general forms of the model based on the two assumptions are specified as follows:

$$
\begin{gathered}
\Delta X_{t}=\beta_{0}+\beta_{1} X_{t-1} \sum_{i=1}^{m} \beta_{2} \Delta X_{t-i}+\varepsilon_{t} \\
\Delta X_{t}=\beta_{0}+\delta t+\beta_{1} X_{t-1} \sum_{i=1}^{m} \beta_{2} \Delta X_{t-i}+\varepsilon_{t}
\end{gathered}
$$

Where $\mathrm{X}$ is a time series, $\mathrm{t}$ is a linear time trend, $\Delta$ is the first difference operator, $\beta_{0}$ is a constant, $i$ is the optimum number of lags in the independent variables, and $\varepsilon_{\mathrm{t}}$ is random error term. Equation (3) represents the ADF unit root test based on the constant with no trend assumption; while Equation (4) follows the constant with a linear deterministic time trend. The null hypothesis for the test is that $X_{t}$ contains a unit root and is specified as follows:

$$
H_{0}: \beta_{1}=1
$$

Against the alternative hypothesis that:

$$
H_{1}: \beta_{1} \neq 1
$$

If the estimated $\beta_{1}$ is significantly less than 0 as measured by a $\tau$-test (read as tau test), then we can reject the null hypothesis of a unit root; this implies that the variable is stationary. If the estimated $\beta_{1}$ is not significantly less than 0 , then we cannot reject the null hypothesis of a unit root; this implies that the variable is nonstationary [19].

The unit root test is followed by a bounds test for cointegration. The bounds test is utilized to determine whether there exists long run equilibrium relationship in the ARDL framework. The existence of a long run relationship is defined by the significance of the F-statistic at a given level of significance.

The existence of long run relationship leads us to the estimation of the vector error correction model defined under the ARDL framework as follows:

$$
\begin{gathered}
\Delta I N F_{t}=\beta_{0}+\sum_{i=1}^{P} \beta_{1 i} \Delta I N F_{t-i}+\sum_{i=1}^{q} \beta_{2 i} \Delta M P R_{t-i}+\sum_{i=1}^{q} \beta_{3 i} \Delta T B R_{t-i}+\sum_{i=1}^{p} \beta_{4 i} \Delta L R A_{t-i}+\sum_{i=1}^{q} \beta_{5 i} \Delta M 2 G_{t-i}+ \\
\sum_{i=1}^{q} \beta_{6 i} \Delta P L R_{t-i}+\sum_{i=1}^{q} \beta_{7 i} \Delta U N M_{t-i}+\sum_{i=1}^{q} \beta_{8 i} \Delta G O V_{t-i}+\lambda E C M_{t-1}+\mu_{\mathrm{t}}
\end{gathered}
$$

Where:

$\lambda=\left(1-\sum_{i=1}^{p} \delta_{i}\right)$, captures the speed of adjustment parameter which is assumed to be negative.

$\mathrm{ECM}=\left(I N F_{t-i}-\theta X_{t}\right)$, the error correction term $\theta=\frac{\sum_{i=0}^{q} \beta_{i}}{\beta}$, is the long-run parameter

$\beta_{1 i}$ to $\beta_{8 i}$ are the short-run dynamic coefficients of the model's adjustment long-run equilibrium. 


\section{Empirical Findings and Discussions}

\subsection{Descriptive Statistics}

The descriptive statistics of the variables utilized in this study is given in Table 2 .

Table 2. Descriptive Statistics of the Series.

\begin{tabular}{lllllll}
\hline Variables & Mean & Minimum & Maximum & Standard Deviation & Skewness & Kurtosis \\
\hline INF & 19.106 & 5.382 & 72.835 & 17.613 & 1.912 & 5.438 \\
MPR & 13.629 & 6.000 & 26.000 & 4.0379 & 0.797 & 5.023 \\
TBR & 12.417 & 3.720 & 26.900 & 4.8473 & 0.869 & 4.524 \\
LRA & 46.075 & 29.100 & 64.100 & 9.3275 & 0.010 & 2.591 \\
M ${ }_{2}$ & 25.122 & 1.294 & 57.7815 & 15.437 & 0.551 & 2.443 \\
PLR & 18.683 & 13.542 & 29.800 & 3.1451 & 1.772 & 7.271 \\
UNM & 4.0738 & 3.424 & 6.2370 & 0.6912 & 2.164 & 6.821 \\
GOV & 21.507 & -26.025 & 106.071 & 28.896 & 1.352 & 5.130 \\
\hline
\end{tabular}

Source: Output extracted from Eviews 10.

It is observed that inflation averaged $19.11 \%$ within the study period with a standard deviation of $17.61 \%$. The highest inflation rate within the study period is $72.84 \%$ which was recorded in 1995 and the minimum is $5.38 \%$ experienced in 2007. In 1995 where we had the highest inflation rate, key issues need to be noted. One of it is that the previous years' (1994) growth rate of broad money supply was as high as $34.50 \%$ and government expenditure grew by a record high of $54.62 \%$ in the year 1995. Though MPR remained stable at 13.50 , the growth in government expenditure can be a driving force in creating high inflation as at that date. Similarly, the growth rate of broad money supply averaged $25.12 \%$ with a standard deviation of $15.44 \%$. The minimum value was $1.29 \%$ as at 2013 while the maximum was $57.78 \%$ as at 2008 . Growth rate of total government expenditure averaged $21.51 \%$ with a minimum of $-26.025 \%$ in 2000 and a maximum of $106.07 \%$ in 1993. It is worth noting that in the period where we had $106.07 \%$ growth in total government expenditure, inflation was as high as $57.17 \%$ while as at 2000 when the growth rate was -
$26.025 \%$, inflation was $6.93 \%$. This indicates that though monetary policy is often regarded to be a vital too for tackling inflation, a sustainable monetary-fiscal coordination is necessary. This point is subject to verification when we will be examining such effect empirically.

The descriptive statistics of other variables are fully displayed in the table. An interesting point to note about all the variables is that they are positively skewed. This implies that the variables tilt to increase rather than decreasing. Kurtosis is moderate for liquidity ratio and growth rate of broad money supply but high for prime lending rate and unemployment.

\subsection{Unit Root Test}

The Augmented Dickey-Fuller test result for the stationarity of the series is presented in Table 3. The result displays the stationarity of the series under the assumptions of constant with no trend, and constant with a time trend.

Table 3. Unit Root Test Result.

\begin{tabular}{|c|c|c|c|c|c|c|}
\hline \multicolumn{3}{|c|}{ Constant Assumption } & \multicolumn{4}{|c|}{ Constant and Deterministic Trend Assumption } \\
\hline Variable & Level & First Difference & Order of Integration & Level & First Difference & Order of Integration \\
\hline INF & $-2.2238(0.2029)$ & $-3.4087(0.0203)^{* *}$ & $\mathrm{I}(1)$ & $-2.8310(0.1991)$ & $-4.1358(0.0167)^{* *}$ & $\mathrm{I}(1)$ \\
\hline MPR & $-3.1866(0.0296)^{* *}$ & $-8.0654(0.0000)^{* * *}$ & $\mathrm{I}(0)$ & $-3.5421(0.0507)^{*}$ & $-7.9730(0.0000)^{* * *}$ & $\mathrm{I}(1)$ \\
\hline TBR & $-2.9398(0.0512)^{*}$ & $-6.7410(0.0000)^{* * *}$ & $\mathrm{I}(1)$ & $-3.4118(0.0665)^{*}$ & $-6.6874(0.000)^{* * *}$ & $\mathrm{I}(1)$ \\
\hline LRA & $-3.1027(0.0358)^{* *}$ & $-7.0624(0.0000)^{* * *}$ & $\mathrm{I}(0)$ & $-3.4949(0.0560)^{*}$ & $-7.03840 .0000)^{* * *}$ & $\mathrm{I}(1)$ \\
\hline $\mathrm{M}_{2} \mathrm{G}$ & $-3.6195(0.0105)^{* *}$ & $-8.4155(0.0000) * * *$ & $\mathrm{I}(0)$ & $-3.9858(0.0189)^{* *}$ & $-8.4233(0.0000)^{* * *}$ & $\mathrm{I}(0)$ \\
\hline UNM & $-3.2761(0.0272)^{* *}$ & $-3.9009(0.0072)^{* * *}$ & $\mathrm{I}(0)$ & $-3.2786(0.0929) *$ & $-4.0365(0.0220)^{* *}$ & $\mathrm{I}(1)$ \\
\hline GOV & $-1.4978(0.5210)$ & $-3.6692(0.0102)^{* *}$ & $\mathrm{I}(1)$ & $\begin{array}{l}-9.4481 \\
(0.0000)^{* * *}\end{array}$ & $-3.5550(0.0520)^{*}$ & $\mathrm{I}(0)$ \\
\hline
\end{tabular}

Note: $* * *, * *$, and $*$ denotes significance at the $1 \%, 5 \%$, and $10 \%$ level respectively.

Source: Output extracted from Eviews 10.

Under the constant no trend assumption, MPR, LRA, $\mathrm{M}_{2} \mathrm{G}$, PLR, and UNM are stationary at levels whereas INF, TBR, and GOV became stationary after being differenced once. However, the constant and time trend assumption presents the fact that $\mathrm{M}_{2} \mathrm{G}$, PLR, and GOV are stationary at level while all other variables are stationary at first difference. One key issue to note is that both assumptions presents the variables to be in mixed order of integration. This mixed order of integration prompts the use of the ARDL Bounds test for cointegration to determine whether there is any long 
run relationship. The result of the Bounds test for cointegration is presented in Table 4.

\subsection{Bounds Test for Cointegration}

The result of the bounds test is presented below.

Table 4. Bounds Test for Co-integration.

\begin{tabular}{lllll}
\hline Test Statistic & Value & Significance & Upper Bounds I(0) & Lower Bounds I(1) \\
\hline F-statistic & 49.642 & $10 \%$ & 1.92 & 2.89 \\
Number of variables $(\mathrm{k})$ & 7 & $5 \%$ & 2.17 & 3.21 \\
& & $2.5 \%$ & 2.43 & 3.51 \\
& & $1 \%$ & 2.73 & 3.9 \\
\hline
\end{tabular}

Source: Output extracted from Eviews 10.

The bounds test result presents evidence of long run relationship among the variables. This is because the F-statistic is statistically significant at the $1 \%$ level as the F-statistic is greater than the upper and lower bounds at each of the respective significance levels. Hence, the null hypothesis of no levels relationship is rejected. The existence of this long run relationship forms the basis for the estimation of the error correction model of which the result is presented in Table 5.

\subsection{Error Correstion Mechanism}

The result of the error correction model is presented below.

Table 5. Vector Error Correction Mechanism.

\begin{tabular}{|c|c|c|c|c|}
\hline \multicolumn{5}{|c|}{ Dependent Variable: $\Delta(I N F)$} \\
\hline Variable & Coefficient & Std. Error & t-Statistic & Probability \\
\hline$\Delta(\mathrm{MPR})$ & -4.025 & 0.144 & -27.897 & $0.0013 * * *$ \\
\hline$\Delta(\operatorname{MPR}(-1))$ & 1.585 & 0.135 & 11.691 & $0.0072 * * *$ \\
\hline$\Delta(\operatorname{LRA}(-1))$ & 0.464 & 0.029 & 15.878 & $0.0039 * *$ \\
\hline$\Delta(\mathrm{TBR})$ & 2.112 & 0.104 & 20.251 & $0.0024 * * *$ \\
\hline$\Delta(\operatorname{TBR}(-1))$ & 3.065 & 0.104 & 29.372 & $0.0012 * * *$ \\
\hline$\Delta(\operatorname{PLR}(-1))$ & 2.308 & 0.090 & 25.406 & $0.0015 * * *$ \\
\hline$\Delta\left(\mathrm{M}_{2} \mathrm{G}\right)$ & 0.483 & 0.018 & 25.604 & $0.0015^{* * *}$ \\
\hline$\Delta\left(\mathrm{M}_{2} \mathrm{G}(-1)\right)$ & 0.079 & 0.015 & 5.095 & $0.0364 * *$ \\
\hline$\Delta(\mathrm{UNM})$ & -30.333 & 1.063 & -28.519 & $0.0012 * * *$ \\
\hline$\Delta(\mathrm{UNM}(-1))$ & 31.648 & 0.996 & 31.775 & $0.0010 * * *$ \\
\hline$\Delta(\mathrm{GOV})$ & 0.373 & 0.012 & 29.904 & $0.0011 * * *$ \\
\hline$\Delta(\operatorname{GOV}(-1))$ & 0.155 & 0.012 & 12.686 & $0.0062 * * *$ \\
\hline $\operatorname{ECM}(-1)$ & -0.554 & 0.011 & -47.264 & $0.0004 * * *$ \\
\hline \multicolumn{2}{|c|}{ Adjusted R-squared $=0.9934$} & \multicolumn{3}{|c|}{ Durbin-Watson $=1.86$} \\
\hline
\end{tabular}

Note: $* * *, * *$, and $*$ denotes significance at the $1 \%, 5 \%$, and $10 \%$ level respectively.

Source: Output extracted from Eviews 10.

The result of the ECM shows that $55.4 \%$ of the short run disequilibrium is corrected annually. This is based on the fact that the ECM coefficient is rightly signed (negative) and statistically significant at the $1 \%$ level of significance. The Rsquared (0.9972) indicates that the explanatory variables explains $99.72 \%$ of the variations in the rate of inflation while the remaining $0.28 \%$ is explained by factors not considered in the model. However, such R-squared value is quite high and presents a good fit of the regression line. The R-squared remained still high (0.9934) after being adjusted for the degree of freedom.

From the short-run dynamic coefficients of the model's adjustment long-run equilibrium, MPR is observed to exert a negative and significant effect on inflation. Thus, a unit percentage increase in MPR will reduce inflation by $4.025 \%$. Also, liquidity ratio and treasury bills rate are observed to impact positively on inflation. That is, an increase in LRA and TBR will lead to an increase in inflation. Thus, a unit percentage increase in LRA and TBR will lead to a $1.03 \%$ and $2.301 \%$ increase in inflation respectively. Similarly, growth rate of broad money supply and growth rate of government expenditure positively and significantly influence inflation. The magnitude of this effect is that a unit percentage increase in $\mathrm{M}_{2} \mathrm{G}$ and GOV will lead to a $0.483 \%$ and $0.373 \%$ increase in inflation. Unemployment is observed to exert a negative and significant impact on inflation. This is in line with the Philips postulation that there exist an inverse relationship between inflation and unemployment. Also, such negative and significant effect portrays the existence of the trade-off between inflation and unemployment. A policy of lower unemployment through monetary policy stance will lead to high inflation due to the existence of lags in monetary policy. Thus, a unit percentage increase in unemployment will lead to a $30.33 \%$ decrease in inflation in the short run.

Then, interest rate also exerts a negative and significant effect on inflation. A unit percentage increase in interest rate will lead to a $1.717 \%$ decrease in inflation. It is worth noting that the lag values of all these variables also exert a significant effect on the rate of inflation in the short run. Also, all the channels through which monetary policy can pass through to affect inflation are 
all statistically significant in influencing inflation. The implication is that monetary policy is effective in combating inflation in Nigeria. Meanwhile, the study also reveals that the growth rate of total government expenditure is statistically significant in curbing inflation. Thus, showing the need for a monetary-fiscal coordination.

\subsection{Stability Test}

The cumulative sum (CUSUM) of squares lies within the $5 \%$ upper and lower bounds. The implication is that the coefficients are stable. This is shown in Figure 2.

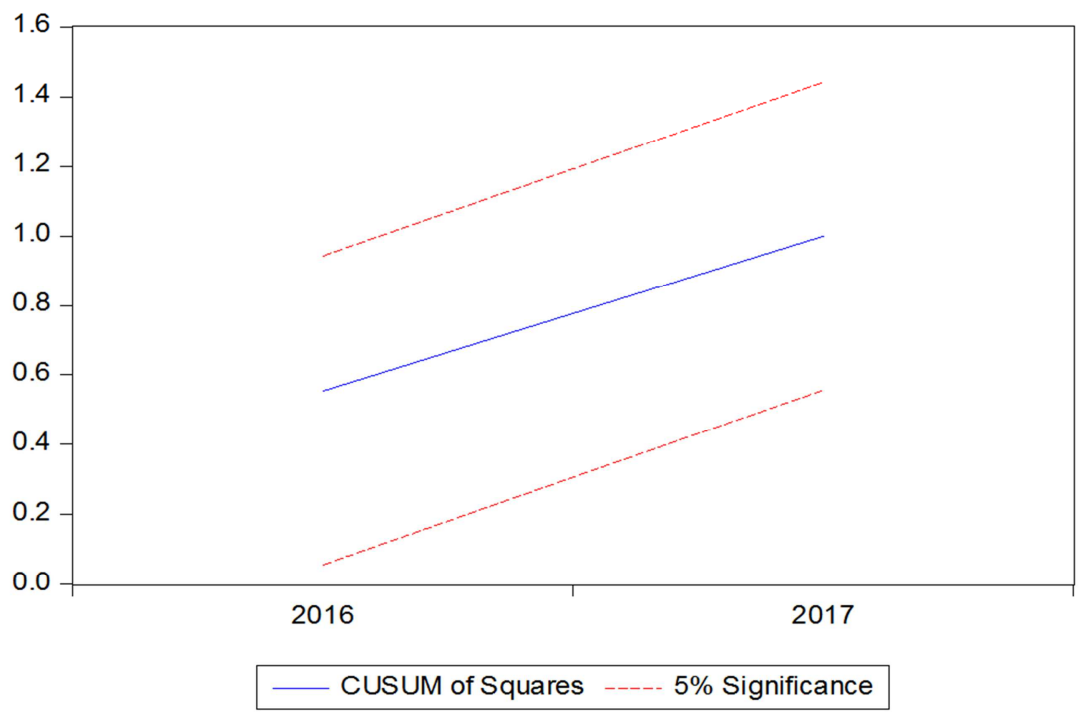

Figure 2. The CUSUM of Squares Test for Stability.

Thus, our short run coefficients can truly be used for inferences.

\subsection{Heteroscedasticity Test}

To determine whether there is a constant variance, the Heteroskedasticity test is conducted and the result presented in Table 6.

Table 6. Heteroskedasticity Test: Breusch-Pagan-Godfrey.

\begin{tabular}{llll}
\hline F-statistic & 0.963408 & Prob. F(22,2) & 0.6291 \\
Observed R-squared & 22.8443 & Prob. Chi-Square(22) & 0.4106 \\
Scaled explained SS & 0.07004 & Prob. Chi-Square(22) & 1.0000 \\
\hline
\end{tabular}

Source: Output extracted from Eviews 10.

Since none of the test statistics are significant, there is no heteroscedasticity in the model. Therefore, our variables are homoscedastic, having a constant variance.

\subsection{Long Run Coefficients}

The long run equilibrium result is presented in the below.

Table 7. Long Run Estimates.

\begin{tabular}{lllll}
\hline Dependent Variable: INF & & & & Probability \\
\hline Variable & Coefficient & Std. Error & -2.690 & $0.0442^{* *}$ \\
\hline MPR & -3.583 & 1.331 & 8.976 & $0.0122^{* *}$ \\
LRA & 3.548 & 0.395 & -1.108 & 0.3833 \\
PLR & -1.545 & 1.395 & 6.854 & $0.0206^{* *}$ \\
$\mathrm{M}_{2} \mathrm{G}$ & 1.287 & 0.187 & 2.865 & $0.0433^{* *}$ \\
TBR & 4.502 & 1.371 & -2.195 & 0.1593 \\
UNM & -19.519 & 8.890 & 7.351 & $0.0180^{* *}$ \\
GOV & 1.583 & 0.215 & $0.0499^{* *}$ \\
C & 189.348 & 43.943 & 4.308 & \\
\hline
\end{tabular}

Note: $* * * * *$, and $*$ denotes significance at the $1 \%, 5 \%$, and $10 \%$ level respectively.

Source: Output extracted from Eviews 10.

Our long run result supports our short run result presented in Table 7. It is observed that monetary policy channels that 
will significantly affect inflation in the long run are the MPR, LRA, $M_{2} G$, and TBR while fiscal policy through government expenditure is also observed to exert a significant long run effect. In the long run, a unit percentage increase in MPR will lead to a $3.583 \%$ decrease in inflation while a unit percentage increase in liquidity ratio will lead to $3.548 \%$ increase in inflation. Similarly, a unit percentage increase in the growth rate of money supply will lead to a $1.287 \%$ increase in inflation, while such a unit increase in treasury bills rate will yield a $4.502 \%$ increase in inflation. Growth rate of government expenditure is also seen to increase inflation by $1.583 \%$ in the long run if it is increased by $1 \%$.

From the foregoing, it is observed that monetary policy is also an effective inflation targeting tool in the long run. However, there should be a coordination in the implementation of monetary policy. The implication is that policies should not conflict. For instance, if the monetary authority seeks to embark on reducing inflation through a contractionary monetary policy, government on her own part should not embark on deficit financing as such effort will counter the effectiveness of the monetary policy. Similarly, government effort to combat inflation through a surplus budget should not be matched with the monetary authority's action of increasing the money supply. In all, the need for a monetary-fiscal coordination have been identified as being crucial for an effective and efficient inflation targeting.

\section{Conclusion}

The goal of price stability has been regarded as one of the major aim of monetary policy. This study examined the effectiveness of monetary-fiscal coordination in inflation targeting in Nigeria. The study cuts across the period 1985 to 2019. The study reveals that the various channels through which monetary policy can influence inflation (MPR, TBR, LRA, PLR, and $\mathrm{M}_{2} \mathrm{G}$ ) significantly affects inflation in the short run. The bounds test shows that there is a long run relationship between inflation and the explanatory variables in the model. This made us to examine the vector error correction (ECM). The ECM indicates that 55.4\% of the short run disequilibrium is corrected annually.

But in the long run, PLR do not exert any significant relationship. We observed that a unit percentage increase in MPR will reduce inflation by $3.583 \%$ while a unit percentage increase in $\mathrm{M}_{2} \mathrm{G}$ will increase inflation by $1.287 \%$. Also, a unit increase in the growth rate of government expenditure will lead to a $1.583 \%$ increase in inflation. This significant effect of fiscal policy therefore creates the need for a monetary-fiscal coordination.

Based on the findings of this study, the paper concludes by stating that there is a need for a sound monetary-fiscal coordination in the Nigerian economy if the fight against inflation is to be won. It follows that inflation should not only be viewed as a monetary phenomenon rather, a call for concern from both the monetary and fiscal arena. As noted by Bassey and Essien [20], the extent of the success of Inflation Targeting, if and when adopted, will crucially depend on the availability of executive capacity, quality and timely data and the political will and commitment to the success of the programme on the part of monetary authorities.

\section{References}

[1] Central Bank of Nigeria (2011). Inflation targeting as a monetary policy framework. Understanding monetary policy series No. 12.

[2] Batini, N. and Laxton, D. (2017). Under what conditions can inflation targeting be adopted? The experience of emerging economies.

[3] Masson, P. R., Savastano, M. and Sharma, S. (1997). The scope for inflation targeting in developing countries. IMF Working Paper No. WP/97/130, Washington, DC: IMF Research Department.

[4] Okwori, J. and Abu, A. (2017). Monetary Policy and Inflation Targeting in Nigeria. International Journal of Economics and Financial Management, 2 (3), 1-12.

[5] Aliyu, U. R. and Englama, A. (2009), "Is Nigeria ready for inflation targeting? Available online at http://mpra.ub.unimuenchen.de/14870/mprapaperNo.14870.pdf.

[6] Tolulope, A. O. and Ajilore, T. (2013). Inflation targeting monetary policy rule in Nigeria: Estimates of the policy reaction function. International Journal of Economics and Finance, 5 (7), 139-144.

[7] Central Bank of Nigeria (2019). CBN Statistical Bulletin. Abuja.

[8] Friedman, M. (1968), "The Quantity Theory of Money". International Encyclopaedia of Social Sciences, London, Corwell Collier and Macmillan, Inc. Vol. 10.

[9] Mishkin, F. S. and Savastano, M. A. (2008). Monetary policy strategies for emerging market countries: Lessons from Latin America. Manuscript, Columbia University.

[10] Naraidooa, R. and Gupta, R. (2009). Modelling monetary policy in South Africa: Focus on inflation targeting era using a simple learning rule. University of Pretoria, Department of Economics Working Paper Series, Working Paper: 2009-04, January.

[11] Kadioglu, F., Ozdemir, N. and Yilmaz, G. (2009). Inflation targeting in developing countries. The Central Bank of the Republic of Turkey, Discussion Paper, September.

[12] Gerlach, S. and Tillmann, P. (2011). Inflation targeting and inflation persistence in Asia-Pacific. Hong Kong Institute for Monetary Research Working Paper No. 25/2011.

[13] Poon, W. C. and Kok, T. G. (2011). The feasibility of inflation targeting in Malaysia. Economics Bulletin, 29, 1036-1046.

[14] Danjuma, I., Jibrin, S. M. and Blessing, S. E. (2012). An assessment of the effectiveness of monetary policy in combating inflation pressure on the Nigerian economy. Erudite Journal of Business Administration and Management (EJBAM), 1 (1), 7-16.

[15] Chinaemerem, C. O. and Akujuobi, L. E. (2012). Inflation targeting and monetary policy instruments: Evidence from Nigeria and Ghana. Arabian Journal of Business and Management Review, 1 (11), 52-81. 
[16] Odior, E. S. O. (2012). Inflation targeting in an emerging market: VAR and impulse response function approach. European Scientific Journal, 8 (6), 79-98.

[17] Maku, A. O. and Adelowokan, O. A. (2013). Dynamics of inflation in Nigeria: An autoregressive approach. European Journal of Humanities and Social Sciences, 22 (1), 1175-1184.

[18] Aigbedion, I. M. (2017). Inflation targeting as a monetary policy in Nigeria: An application of vector autoregressive (VAR) model. Journal of Economics and Sustainable Development, 8 (7), 59-68.
[19] Studenmund, A. H. and Johnson, B. K. (2017). Using econometrics: A practical guide (seventh edition). Boston: Pearson.

[20] Bassey, G. E. and Essien, E. B. (2014). Inflation targeting framework for monetary policy in Nigeria: Issues, problems and prospects. Journal of Economics and Sustainable Development (JESD), 5 (8), 88-101. 